\author{
D. L. Hopkins \\ University of Florida, Mid-Florida Research and Education Center, Apopka
}

A. H. Purcell

University of California, Berkeley

\title{
Xylella fastidiosa: \\ Cause of Pierce's Disease of Grapevine and Other Emergent Diseases
}

Over the past decade, plant diseases caused by the bacterium Xylella fastidiosa have emerged as some of the most significant new disease threats in the Americas. These diseases fit into the category of "emerging diseases" that either have not been previously noticed or have risen from recent obscurity to become prominent problems. For some of these diseases, the introduction of exotic strains of $X$. fastidiosa resulted in new host-pathogen combinations; for example the emergence of citrus variegated chlorosis disease (CVC) in southern South America in the 1980s (73) and the appearance of oleander leaf scorch disease in California in the mid-1990s (68).

The reason that a relatively obscure plant pathogen such as $X$. fastidiosa was the first nonviral plant pathogen to have its genome completely sequenced was its sudden rise to prominence in Brazil as the cause of CVC, a disease first noted in only a few orange trees in 1987 (73). By 1992, over 2 million trees had been affected (44), and today over a third of the orange trees (120 million) in the world's largest citrusgrowing region have CVC symptoms (see the Fundecitrus website). The disease takes its name from the chlorotic foliar lesions that are the first symptoms. Later symptoms are small, unmarketable fruits (Fig. 1). CVC first appeared in Argentina in the 1980s, where it was called pecosita (9). The movement of infected nursery trees probably hastened the rapid spread of CVC throughout Brazil and South America (72).

Coffee leaf scorch disease probably occurred in Brazil for many years, but it was first recognized to be caused by $X$. fas-

Corresponding author: D. L. Hopkins, University of Florida, Mid-Florida Research and Education Center, 2725 Binion Road, Apopka 32703-8504; E-mail: dlhopkins@mail.ifas.ufl.edu

Florida Agricultural Experiment Station Journal Series R-08993.

Publication no. D-2002-0812-01F

(C) 2002 The American Phytopathological Society tidiosa in the late 1990s, after studies of CVC began (15). Leaves and fruits are dwarfed in diseased coffee plants. Premature fall of leaves and fruits is a more prominent symptom of the disease than scorching. Coffee strains of $X$. fastidiosa are closely related to CVC strains $(10,46)$. Both CVC and coffee leaf scorch are threats to Central America and northern South America. The introduction of CVC strains of $X$. fastidiosa poses serious threats for sweet oranges, mandarins, and tangerines in North America and Mexico.

Still other diseases such as Pierce's disease (PD) of grape in the southeastern United States were long overlooked (25). Ironically, this was because they were so severe and ubiquitous that susceptible crops such as grapes were impossible to grow and thus not studied. We will examine in this article how the introduction of a new insect vector, the glassy-winged sharpshooter (Homalodisca coagulata, referred to here as GWSS), changed the basic epidemiology in California of a long- established disease, Pierce's disease of grapes, and what recent findings portend for other plant diseases caused by different strains of $X$. fastidiosa.

\section{Background}

Pierce's disease. The U.S. Bureau of Agriculture's second Bulletin of Vegetable Pathology, The California Vine Disease (56), described an epidemic of a new disease of grape that eliminated commercial viticulture from the Los Angeles Basin of California in the 1880 s. Newton Pierce, one of America's first formally trained plant pathologists, described a severe grapevine disease that had been known as "mysterious disease" and various other names. His detailed descriptions match the key disease symptoms used today to characterize this lethal disease (Fig. 2). However, neither Pierce nor his successors over the next 80 years would be able to detect the bacterium that caused the disease that later came to bear his name. Instead, PD and a malady of peach in the southeastern

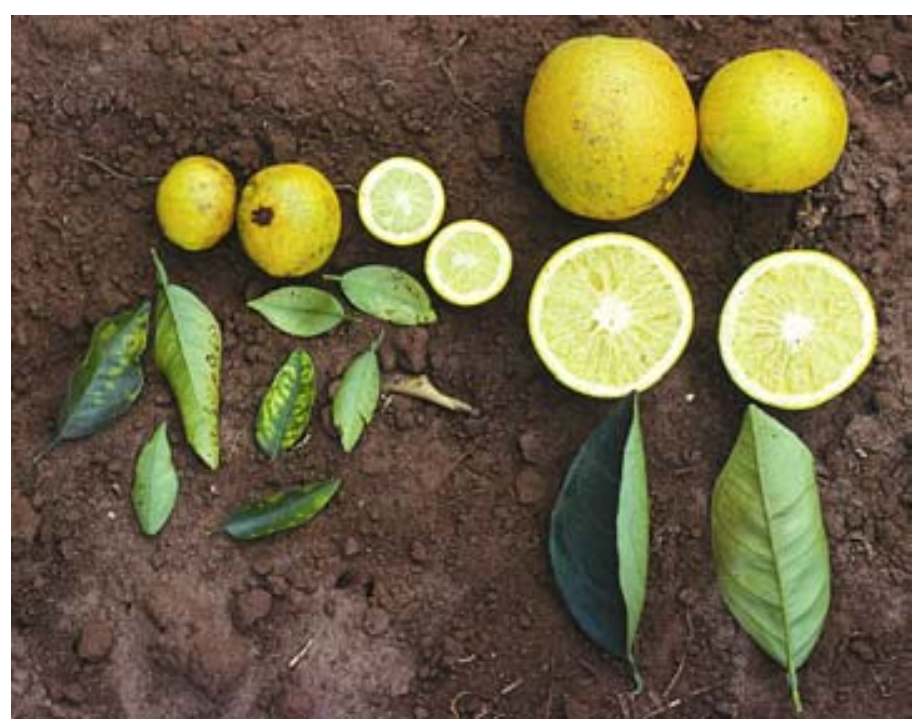

Fig. 1. Chlorotic leaf lesions and small fruit symptoms of citrus variegated chlorosis are on the left; healthy citrus leaves and fruit are on the right. 

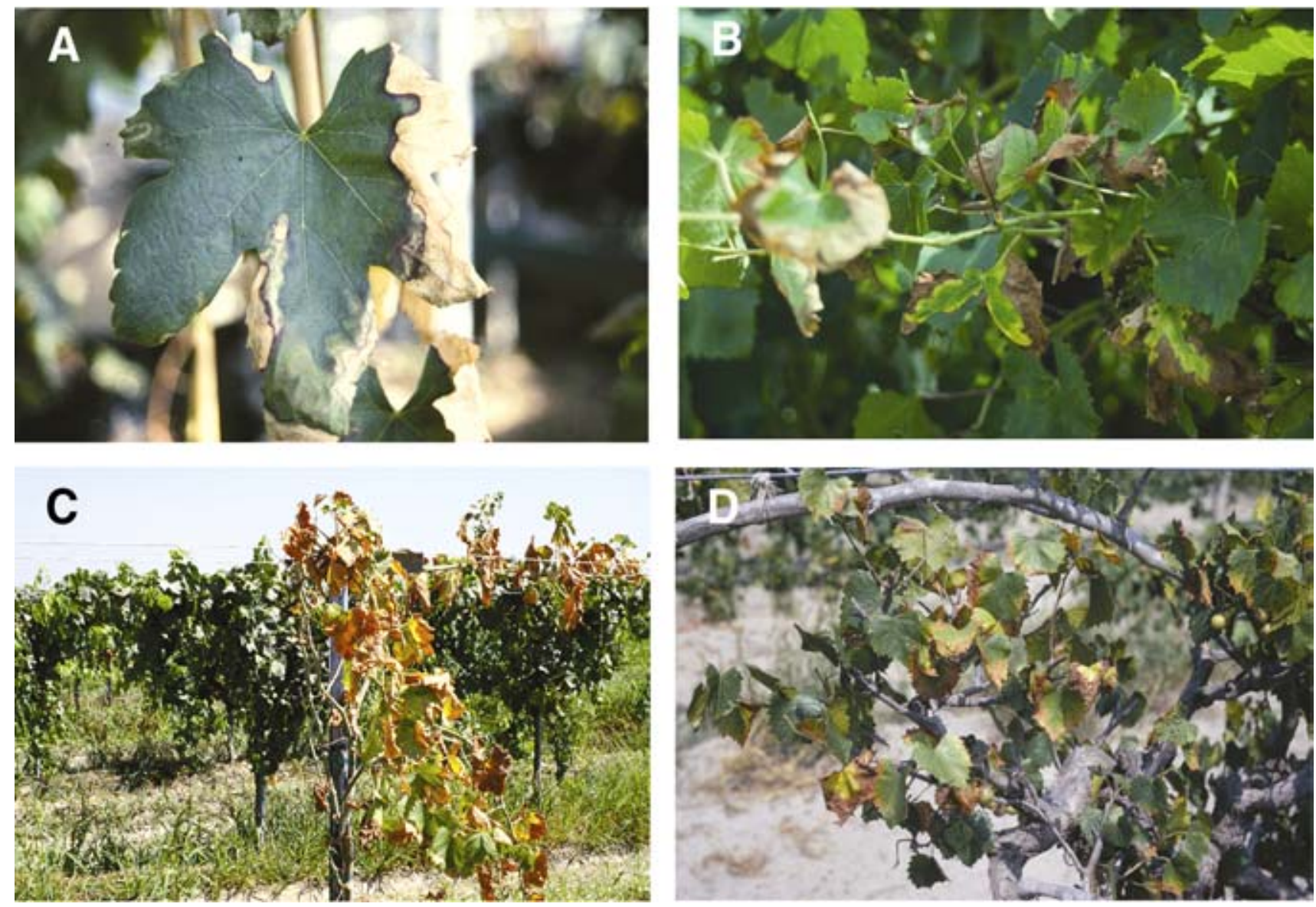

Fig. 2. Pierce's disease of grapevine symptoms: A, leaf marginal necrosis in a red bunch grape; B, leaf marginal necrosis and leaf blade drop with petioles still attached to stem; C, severe leaf scorch symptoms in Fiesta bunch grape (Vitis vinifera) in California; and D, leaf scorch and dieback symptoms in Scuppernong muscadine grape (Vitis rotundifolia) in Florida.

United States known as phony peach disease (Fig. 3) were assumed to be caused by viruses (based on graft and vector transmission experiments) that were restricted to the xylem tissues of their plant hosts $(8,27)$.

Over 50 years later, an epidemic of PD in northern California prompted new research efforts. One of the major discoveries during this period (1939 to 1945) was that xylem sap-sucking insects such as sharpshooters (subfamily Cicadellinae in the leafhopper family Cicadellidae) and spittlebugs (family Cercopidae) were vectors of the PD pathogen $(17,27,41)$. However, even excellent control of vectors within vineyards and the prompt removal of diseased vines did not decrease the subsequent rate of increase of PD in California (26). In addition, spatial patterns of PD within vineyards implied that the pathogen was spread into vineyards from outlying areas that harbored breeding populations of vector insects, suggesting that vine-to-vine spread of PD was minimal. Especially noteworthy was the early association between a newly described alfalfa disease, alfalfa dwarf (AD), and PD. The incidence of PD in vineyards was typically highest adjacent to alfalfa fields with $\mathrm{AD}$, and the incidence of the disease decreased with distance from alfalfa (28). Histological studies of $\mathrm{AD}$ produced the first photo-

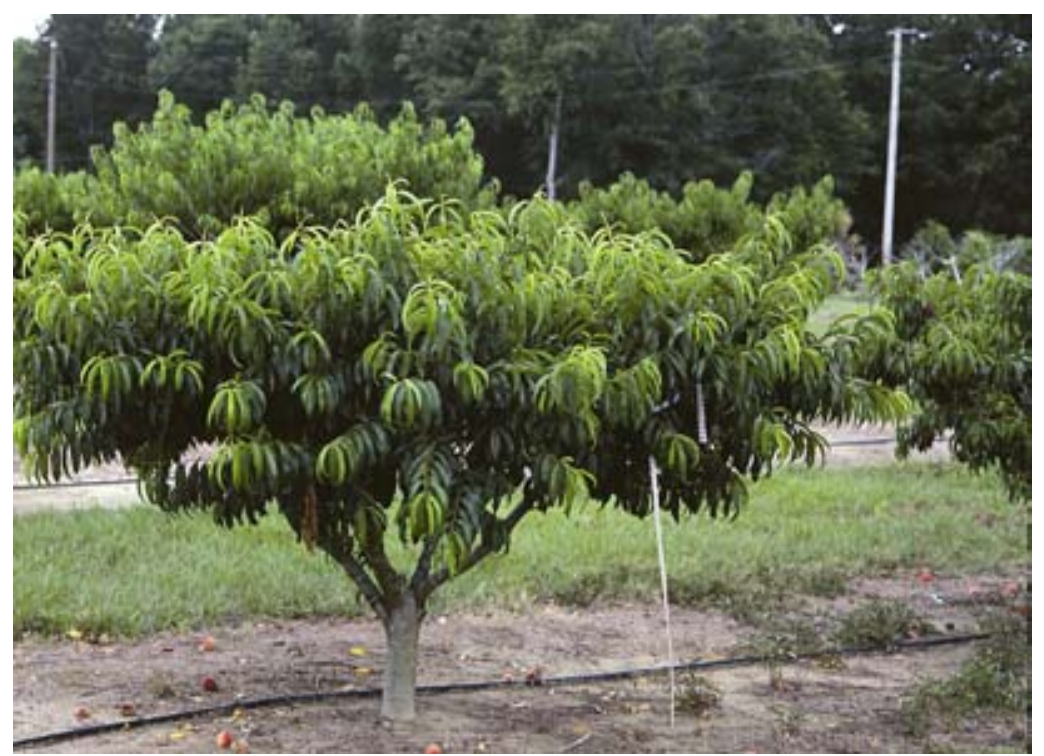

Fig. 3. Phony peach disease symptoms include stunted tree with dwarfed new growth and shortened stem internodes.

graphs of "bacteria-like bodies" that were consistently associated with AD symptoms (Fig. 4) (88). But it would be over 40 years before these "bodies" were proven to be bacteria that caused both AD and PD (12). The findings that a wide range of plant species hosted the causal pathogen (18) reinforced the belief that vectors from outside vineyards were the main mode of infection. But the vector transmission characteristics for Pierce's disease made PD's apparent lack of vine-to-vine spread even more puzzling. Vectors did not require any measurable latent period (time between 
pathogen acquisition and first transmission) to efficiently transmit the causal pathogen from grape to grape (65); yet once infective, vectors continued to transmit the pathogen indefinitely (75). So if the bacterium was so easily transmitted from vine to vine in the lab, why wasn't it in the field? The answer was that one of the most basic of plant pathology concepts had been overlooked: infection with a pathogen does not invariably invoke disease. Environment and time also play essential roles.

Host ranges and strain differences. The known list of natural or experimental hosts for all strains of $X$. fastidiosa (there are over 145 for PD strains listed on the website of the College of Natural Resources, University of California, Berkeley) is probably limited more by researchers' limitations in searching for natural or potential hosts than by the bacterium's actual host range. PD strains multiplied in mugwort (Artemisia douglasiana) and watergrass (Echinochloa cruz-galli) with no detectable systemic movement and systemically in blackberry (Rubus procerus) without causing symptoms (30). Fortunately, most PD strains do not move systemically in most symptomless hosts (68), but even nonsystemic hosts can serve as sources for vectors to acquire the bacterium (31).

$X$. fastidiosa causes economic losses in many agriculturally important plants and forest trees in addition to those already mentioned: for example, elm, oak (Fig. 5), oleander, maple, and sycamore (Fig. 6) (Table 1) (23). While all strains of Xylella have been classified into a single species (89), there definitely are different pathotypes and possibly different subspecies (67). Most of the pathotypes have not been characterized and compared with each

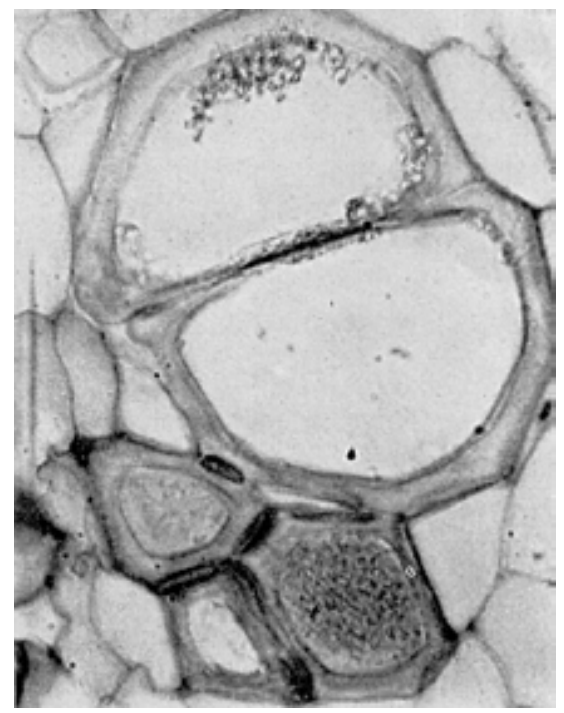

Fig. 4. Cross section of alfalfa root affected by alfalfa dwarf showing bacterialike bodies. Vessels on the left were entirely plugged. (From Weimer 1937, reference 86 ) other. Confusing the issue even more is the probability that genetically distinct strains of the bacterium may produce similar symptoms in a common host (46).

There are distinct differences in the host ranges of different strains of $X$. fastidiosa. Limited numbers of reciprocal transmission tests have been conducted. Pierce's disease of grape, almond leaf scorch (Fig. 7 ), and alfalfa dwarf were shown to be caused by the same strains (29), and phony peach and plum leaf scald were positive in reciprocal transmissions by grafting (91), but peach strains do not cause disease in grape and grape strains do not infect peach (36). Oleander strains did not infect grape, nor did grape strains infect oleander (70), but both strains infected almond (A. H. Purcell, unpublished data). Reciprocal transmission between elm and sycamore leaf scorch strains were negative (76). A CVC strain of $X$. fastidiosa produced leaf scorch disease in coffee (46), and CVC and coffee strains can cause disease in grape under greenhouse conditions (J. Hartung, personal communication). These and a few

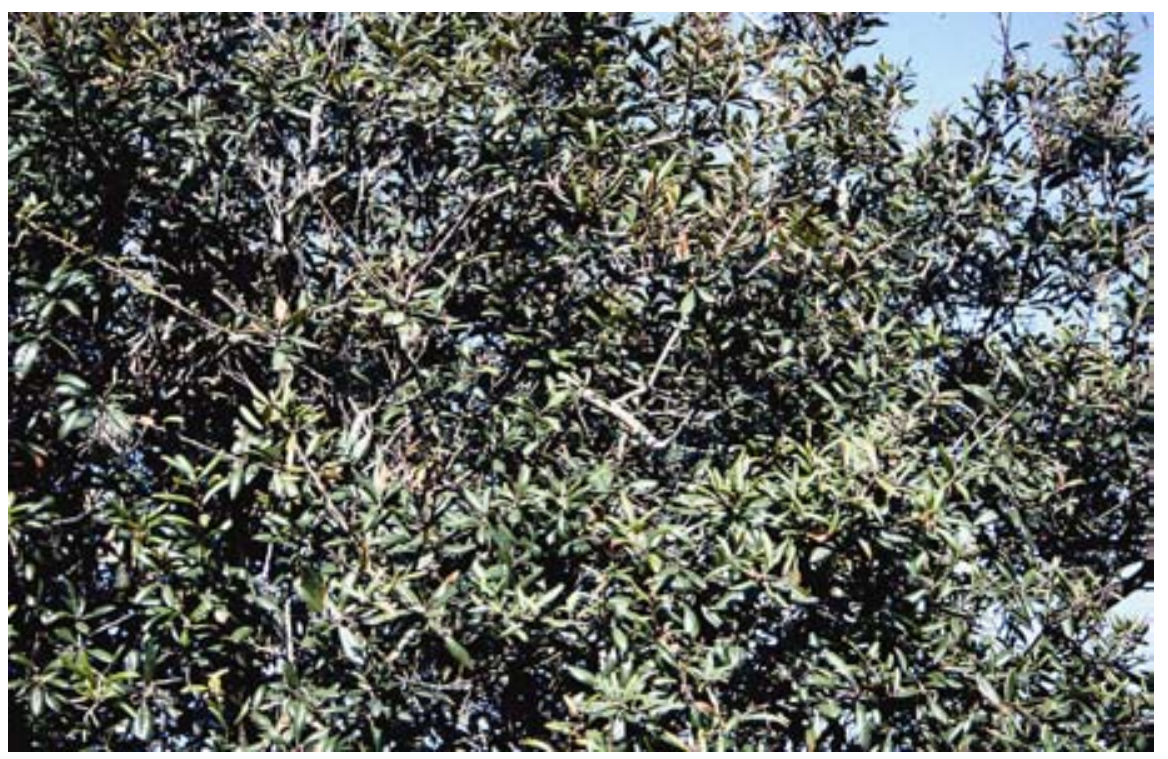

Fig. 5. Oak leaf scorch symptoms in live oak including leaf scorch, leaf drop, and dieback of individual branches.

Table 1. Crop and forest tree diseases confirmed or suspected ${ }^{\mathrm{a}}$ to be caused by Xylella fastidiosa

\begin{tabular}{|c|c|c|}
\hline Plant diseases & Reported occurrence & References $^{b}$ \\
\hline \multicolumn{3}{|l|}{ Grape strains } \\
\hline Pierce's disease & $\begin{array}{l}\text { North and Central Americas, Peru, } \\
\text { Kosovo }\end{array}$ & $4,12,25$ \\
\hline Alfalfa dwarf & California, U.S. & 83,87 \\
\hline Almond leaf scorch & California, Argentina & $14,49,54$ \\
\hline \multicolumn{3}{|l|}{ Peach-plum strains } \\
\hline Phony peach & Southeastern U.S. & 90 \\
\hline Plum leaf scald (U.S.) & $\begin{array}{l}\text { Southeastern U.S.; (see below for } \\
\text { plum strains of unknown affinity) }\end{array}$ & 90 \\
\hline $\begin{array}{l}\text { Citrus variegated chlorosis } \\
\text { (pecosita) }\end{array}$ & Brazil, (Argentina) & 6,22 \\
\hline Coffee leaf scorch & Brazil & 15 \\
\hline \multicolumn{3}{|l|}{ Unknown cross-infectivity strains } \\
\hline $\begin{array}{l}\text { Oak leaf scorch } \\
\text { (related to peach strains) }\end{array}$ & Eastern U.S. & 7,23 \\
\hline Maple leaf scald ${ }^{\mathrm{b}}$ & Eastern U.S. & 78 \\
\hline Elm leaf scorch & Eastern U.S. & 76,92 \\
\hline Sycamore leaf scorch & Eastern U S. & 23,77 \\
\hline Mulberry leaf scorch ${ }^{b}$ & Eastern U.S. & 43 \\
\hline Plum leaf scald (South America) & Paraguay, Brazil & 19,42 \\
\hline Periwinkle wilt & Florida, U.S. & 48,13 \\
\hline Pear leaf scorch (Assoc.) & Taiwan & 45 \\
\hline Pecan leaf scorch & Louisiana, U.S. & 74 \\
\hline Oleander leaf scorch & California and Florida, U.S. & 70 \\
\hline
\end{tabular}

${ }^{\text {a } A s s o c . ~}=$ association only. Koch's postulates not confirmed.

${ }^{\mathrm{b}}$ References are for first report of disease and/or proof that $X$. fastidiosa causes it. 
other studies demonstrate the need for taxonomic characterization of $X$. fastidiosa at the pathovar level. Most strains of $X$. fastidiosa from diseased plants have not been tested for their ability to cause disease in hosts other than those from which they were originally isolated. The results of such tests might be surprising and are fundamental to further progress in studies on ecology, epidemiology, and control of these diseases.

Geographical limits. Diseases caused by $X$. fastidiosa are mainly tropical or subtropical. They seem to be rare or absent from parts of North America with cold winters. The transition from areas of severe to rare or no PD is gradual rather than abrupt. The incidence of PD or phony peach disease in the eastern United States diminishes from the highest levels near the Gulf of Mexico to low levels or absence in the southern midwestern states $(32,61)$. The threat of PD in Texas decreases with distance from the Gulf Coast (Fig. 8). The tolerance of the native wild grapes (Vitis spp.) of the southeastern United States to $X$. fastidiosa and the susceptibility of the Vitis species such as V. labrusca and V. riparia (47) that are native to the northeastern states suggests that this geographic distribution has persisted over evolutionary time. In the Carolinas and Georgia, both $\mathrm{PD}$ and phony peach decrease in incidence with increasing altitude (85). Oak leaf scorch occurs farther north than other diseases caused by various strains of $X$. fastidiosa: as far as Kentucky (21), perhaps as far north as the Niagara peninsula of Canada (20).

Experimental observations that freezing can be therapeutic for PD (61) suggest that winter climate may limit where PD can occur. Temperatures below $10^{\circ} \mathrm{C}$ gradually reduced but did not eliminate populations of the bacterium in grape (16). The maximum growth temperature of $33^{\circ} \mathrm{C}$ for $X$. fastidiosa (16) is surprisingly low for a pathogen that thrives only in tropical and subtropical climates. As will be explained later, the length of the growing season may also be important. PD is more severe in climates that have a longer growing season.

With perhaps two notable exceptions, $X$. fastidiosa has not been reported from outside the Americas. In Taiwan, X. fastidiosa causes a leaf scorch disease of Asian pear (45). PD and other Xylella diseases have been absent in Europe. Massive importations of wild grape rootstocks from America to Europe to counter the grape phylloxera during the nineteenth century should have provided ample opportunity to introduce $X$. fastidiosa into Europe (63). In addition, the very wide range of symptomless hosts of $X$. fastidiosa should have allowed periodic introductions of the bacterium into Europe. Recently, $\mathrm{PD}$ was reported from the Kosovo region of the Balkans (4). Is this the beginning of a ma- jor new problem or yet further evidence that Europe lacks the key factors to sustain epidemics of PD or other Xylella diseases?

\section{A New Vector Changes an Old Problem}

Epidemiology of PD in California prior to GWSS. Although problems were expected to accompany the invasion of GWSS (Fig. 9) into southern California during the 1990s (81), the subsequent rapid spread and severity of PD attributable to GWSS was shocking $(5,55)$. Like other sharpshooters, GWSS is a vector of $X$. fastidiosa, but it differs from traditionally important vectors of $X$. fastidiosa in California in several important aspects. To understand the impact of GWSS in changing the spread of Xylella diseases in California, we must first understand how some underlying factors affect the spread of these diseases by other vector species.

In California's coastal viticultural regions like Napa and Sonoma valleys, PD has been a persistent problem mainly in "PD hot spots" along streams or concentrations of irrigated ornamental landscapes, where an efficient vector, Graphocephala atropunctata (blue-green sharpshooter, BGSS), enters vineyards from its overwintering habitats during spring and summer to feed and often to reproduce on grapevines (26). PD incidence is highest in portions of vineyards along stream bank vegetation and diminishes with distance from such vegetation (57). Only the early-season (March to June) populations of BGSS seemed to have spatial patterns within vineyards (58) that resembled the habitual "edge effect" concentration of PD. A simi-

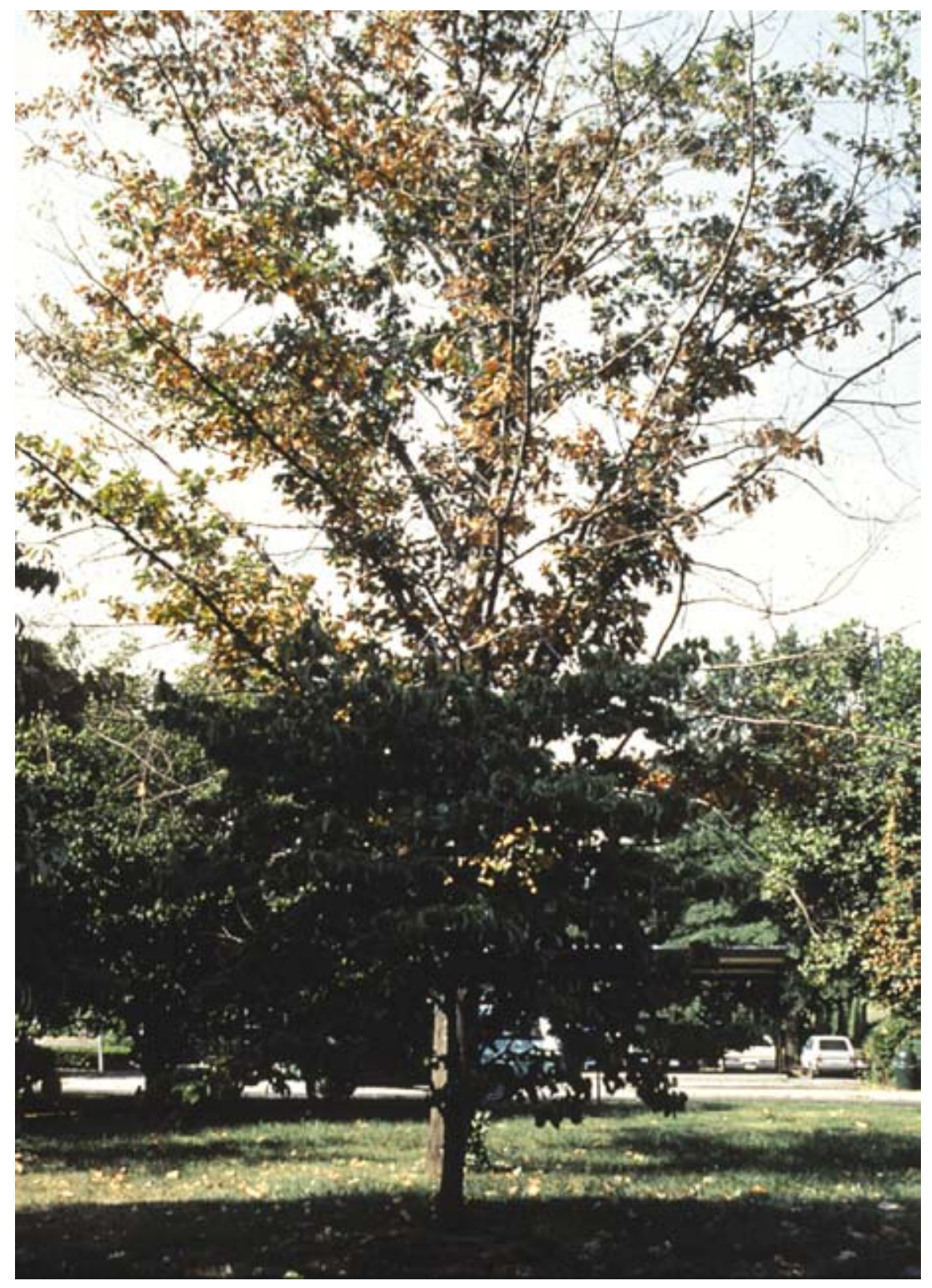

Fig. 6. Sycamore leaf scorch symptoms begin at leaf margins and interveinal tissue and spread to entire leaf. Older leaves are scorched first, but eventually the entire tree may be affected. (With permission of Stan Kostka) 
lar spatial pattern of PD commonly occurs in central California vineyards near breeding habitats of the green and red-headed sharpshooters, such as weedy pastures or hay fields (Fig. 10). After June, populations of newly emerged BGSS adults could become widespread within some vineyards or virtually absent from others because of pesticide treatment; yet the same patterns of PD resulted in either situation. In contrast to the failure of insecticidal control of BGSS within vineyards to reduce future PD spread, insecticides applied against BGSS early in the season to vegetation surrounding vineyards did reduce further PD spread (60). In California's Central Valley, PD has been mainly a problem near typical breeding habitats for two other

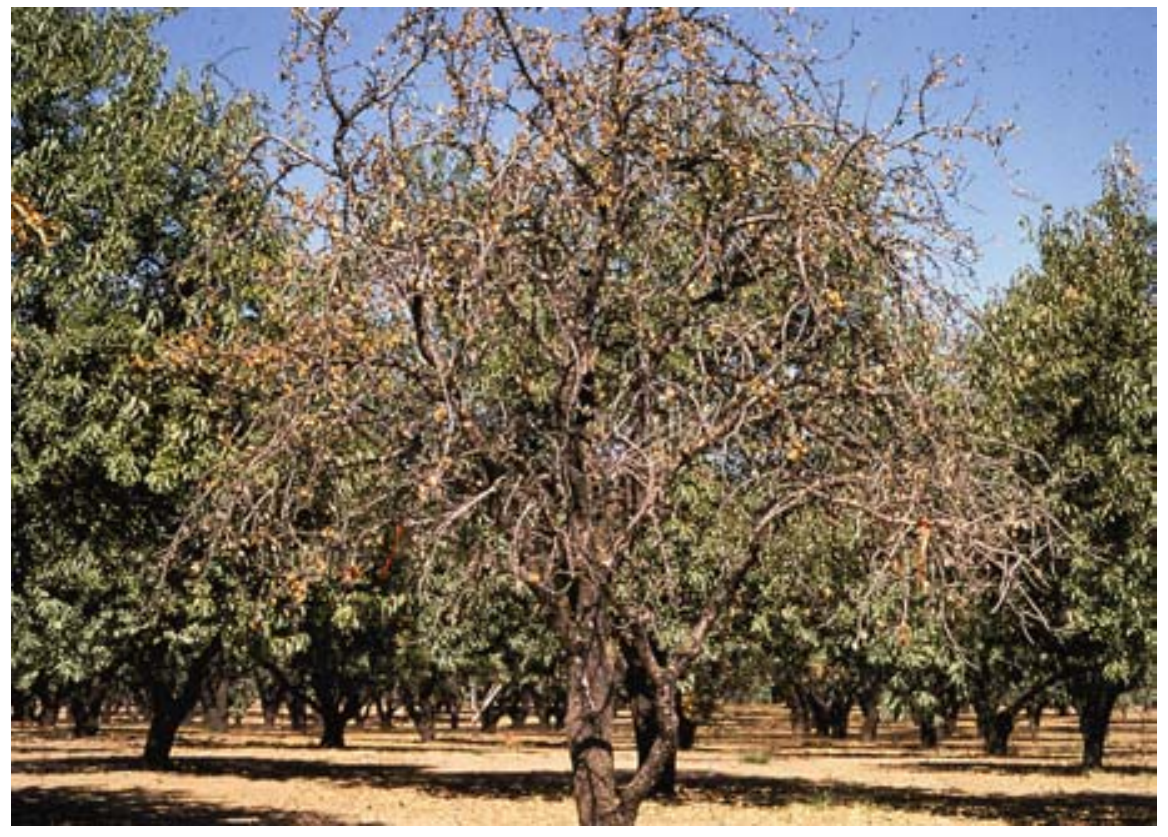

Fig. 7. Severe symptoms of almond leaf scorch. This disease is caused by the same strains that cause Pierce's disease of grapevine.

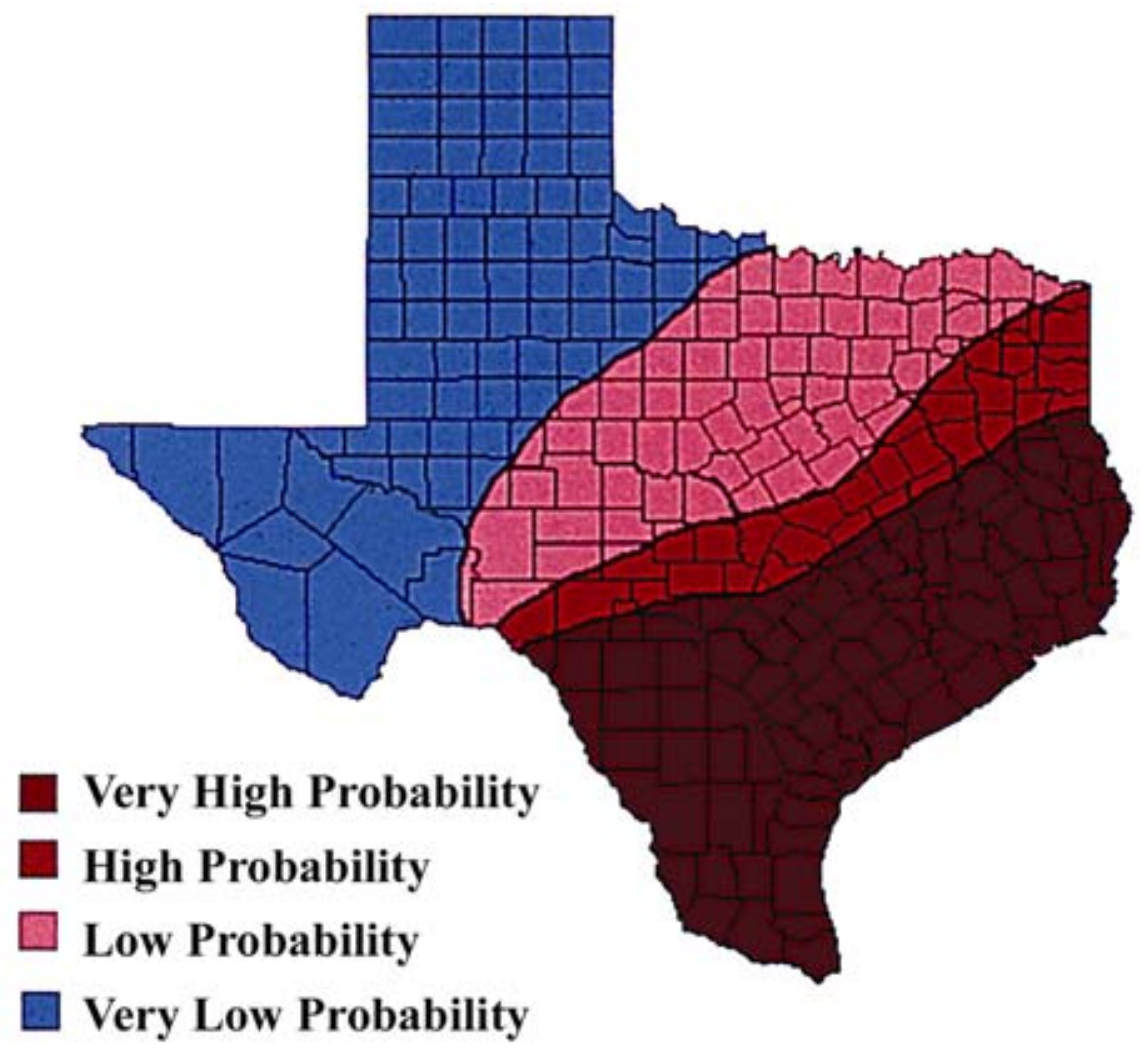

Fig. 8. In Texas, the threat of Pierce's disease of grape diminishes with distance from the Gulf Coast. (With permission of James Kamas)

species of grass-feeding sharpshooters that inhabit pastures and weedy hayfields (26). These two grass-feeding sharpshooters feed on grape only as an "accidental" host (66); yet PD losses in Central Valley vineyards can be substantial despite the difficulty of even detecting vectors on grapevines (26).

The hypothesis proposed to explain the apparent lack of vine-to-vine spread of PD in California is that mainly infections established by overwintered adult vectors that enter vineyards in the spring months establish chronic infections that will persist from year to year (62). This hypothesis assumes that most infections of grape by $X$. fastidiosa during summer months (June to September) either do not occur or do not persist until the following year. Experiments showed that vines are as readily infected in summer as in spring but that only the spring infections were likely to persist until the following year $(62 ; \mathrm{H}$. Feil, Ph.D. diss., 2001, University of California, Berkeley). In these experiments, the vectors inoculated vines near the tips of the growing shoots, where sharpshooters strongly prefer to feed on grape (58). Even using the lowest of a range of observed values of vector densities, movement, and transmission efficiency, an infection model's projections of annual infection far exceeded the levels of new cases of PD actually observed even in vineyards considered to be PD "hot spots" (62), suggesting that many infections do not persist from one year to the next. Why would lateseason infections not lead to chronic disease? One reason may be that pruning eliminates summer infections. Bacterial infections established in April and May do not have to spread as far within the plant to reach the vine's permanent arms or trunk and have more time to spread than do infections of newly grown vine tissues established in summer months. Pruning dormant vines should eliminate many infections that have not reached the grapevine's permanent structure by fall. Another possible explanation for recovery may be that $X$. fastidiosa does not survive winters well in smaller shoots, although the pathogen survived well in cuttings rooted from canes taken in late winter that had been inoculated the previous growing season (16).

The importance of spring infections for causing chronic PD would adequately explain the "edge effect" of PD incidence in California. But why the lack of evidence for vine-to-vine spread of PD? The explanation may be that vine-to-vine spread of $X$. fastidiosa is only likely during summer months. Populations of $X$. fastidiosa in the new growth of grapevines that have been infected in prior seasons only reach numbers sufficient for vector acquisition (31) and spread within new vegetative growth during summer months (80). PD in California served as one of the classic examples of a plant disease that increases at 
"simple interest" rates rather than at the exponential rates typical for the early phases of diseases that progress in a logistic manner (86). Exponential spread is most evident in a disease epidemic where diseased plants provide inoculum for further infection within the crop. The lack of vine-to-vine spread of chronic PD would also explain the ineffectiveness of insecticides to control vectors within vineyards (applied too late) as well as the ineffectiveness of removing diseased vines in reducing the further spread of PD $(26,59)$. California vineyards with PD undoubtedly have had many more nonsymptomatic infections with $X$. fastidiosa than are realized as chronic disease that persists from year to year. We can only guess that the importance of spring infections in establishing chronic PD may explain the lack of PD in Europe, which lacks vectors that overwinter as adults.

Epidemiology of PD in California after GWSS. As for most invasive insects, the year and place of arrival of GWSS into California is unknown. The insect was at first mistaken for Homaladisca lacerta, a species native to the Mohave Desert, but was later identified as $H$. coagulata following its appearance in high numbers on citrus along the coast of southern CaliforAngeles, GWSS was associated in the mid1990s with a new disease of the ornamental shrub oleander (Nerium oleander). Oleanders are widely planted in California along highways, parks, and residential properties. The new disease, oleander leaf scorch, proved to be caused by a strain of $X$. fastidiosa different from those that cause PD (Fig. 11) (70). GWSS feed on oleanders much more readily than most nia $(5,81)$. Along the coast south of Los other sharpshooters in California and appeared to have a major role in spreading oleander leaf scorch in coastal southern California $(5,70)$, but in 1996 the major economic threat that GWSS posed as a vector of $X$. fastidiosa in a major crop in California was not yet evident.

In 1996-97, GWSS were first sighted in and near vineyards in Temecula Valley, an inland desert valley between the Los Angeles Basin and San Diego. Wine grapes and citrus were the main crops produced in Temecula Valley, whose wine production attracted tourism from the nearby urban centers of southern California. In 1997, PD was confirmed from a small Temecula vineyard at the periphery of the agricultural area. The disease in this vineyard was not associated with GWSS and had an "edge effect" pattern typical of PD near riparian areas, and sticky traps in this vineyard did not detect GWSS but instead the willow sharpshooter (Graphocephala confluens) (A. H. Purcell, unpublished data). In 1998, growers and researchers noted large populations of GWSS throughout citrus groves in Temecula Valley. Subsequently, high populations of GWSS moved into adjacent vineyards, and by the end of 1998, new cases of PD were noticed scattered among numerous Temecula Valley vineyards, with over $50 \%$ of the vines in some vineyards with PD symptoms. At the end of 1999, the incidence of PD had reached alarming levels, and the state legislature through the California Department of Food and Agriculture quickly funded new research on GWSS and PD by University of California scientists.

Spatial patterns of PD in Temecula Valley vineyards showed either shallow or diffuse gradients or no significant gradients with distance from citrus sources of GWSS populations. These patterns were consistent with the hypothesis that spread of PD by GWSS was primarily from infected vine sources rather than surrounding environments (55). Since vine-to-vine transmission should only be possible during summer months, has GWSS somehow changed the rate at which summer infections persist to cause chronic disease in California? Or are the spectacular increases in PD with which it has been associated simply caused by its increased presence in vineyards compared with the situation before its arrival? The tendency of adult GWSS to feed at the bases of new shoots or even through the scaly bark of branches on grapevines and

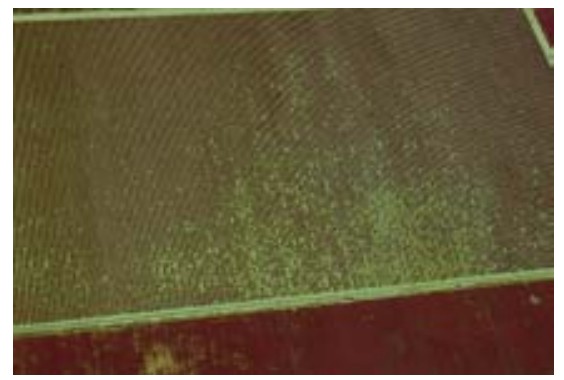

Fig. 10 Pierce's disease (PD) damage (missing vines) in a central California vineyard. The pattern of missing vines and vines with PD symptoms suggests that the former alfalfa field (now cotton) at the bottom of the photo was a source of vectors breeding in grass weeds. The two apparent foci of missing vines were immediately adjacent to an irrigation standpipe, where pooled water leads to heavy infestations of Bermuda grass, a favored host of the main PD vectors. (Photo by Jack Kelly Clark, University of California).
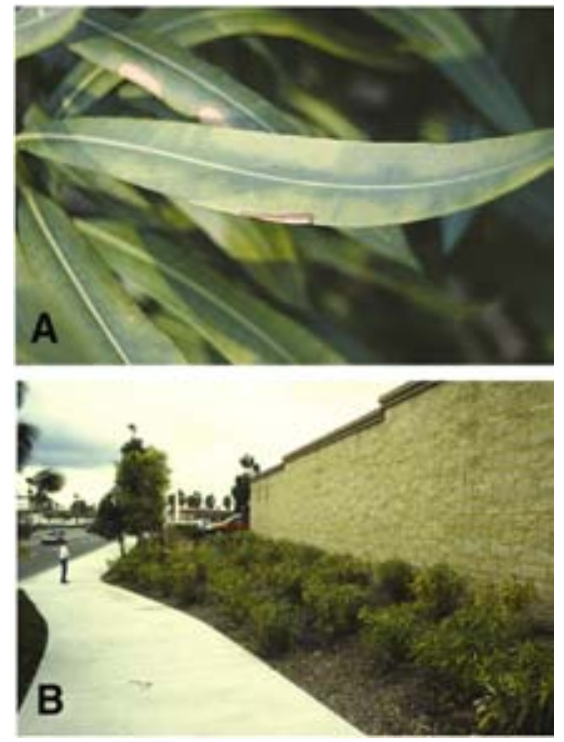
B

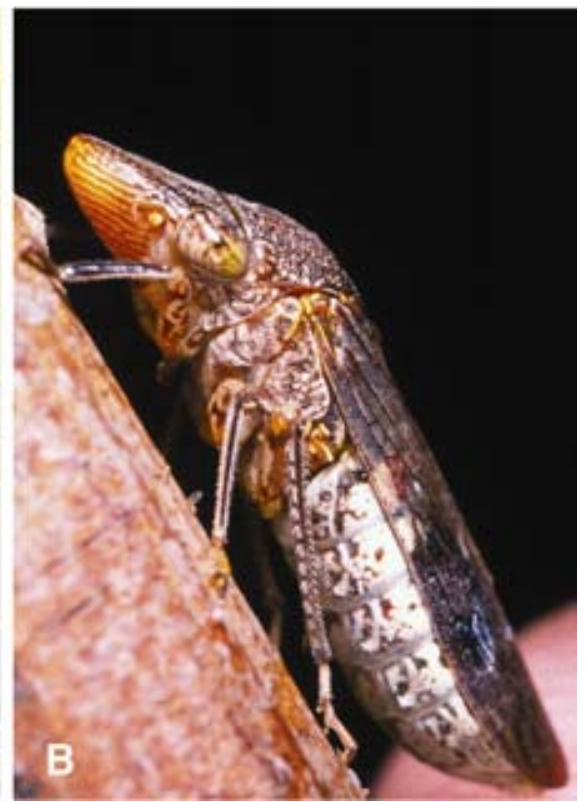

Fig. 9. Glassy-winged sharpshooter (Homalodisca coagulata) on young grape tissue in Florida on the left and a close-up of the sharpshooter on the right. (With permission of Richard Coriella)
Fig. 11. Oleander leaf scorch symptoms: Top, early leaf marginal chlorosis and necrosis symptom; Bottom, every oleander in this California shopping center was symptomatic. 
to feed on dormant vines in winter is radically different from native vectors in California (69). This difference in feeding behavior, by inoculating $X$. fastidiosa into woody portions of shoots, may increase the success of establishing chronic infections during summer (69) In addition, the feeding of infective GWSS on dormant vines may establish chronic infections, adding to the increase in PD. The ability of GWSS to transmit $X$. fastidiosa to dormant vines or its possible impact has not yet been proven, but research is underway to evaluate this possibility. Of course, the numbers of GWSS present in vineyards and their rates of movement from vine to vine are critical to the rate at which GWSS establishes new PD infections in vines (64), and these are only now being explored.

The repercussions of GWSS in California vineyards have been severe in the past few years, but the worst is feared to lie ahead, as the insect continues to expand its range northward on the Pacific Coast. The southern half of the Central Valley harbors the majority of California's wine, table, and raisin grapes, as well as much of the state's citrus. Before 1998, growers at the southern end of the Central Valley had noticed high GWSS populations from citrus that migrated into nearby vineyards and other crops such as cherry. No PD had been seen in the region (Kern County) for over 50 years, and the large numbers of GWSS in citrus and later in the season in grape raised few immediate concerns. This situation changed dramatically in the late summer of 2000, when the first few cases of PD were verified as occurring in vineyards that had been heavily occupied by GWSS in that and previous years. Prompted by the fresh memories of the Temecula situation in 1999 to 2000 , plans were begun in 2000 to improve control of GWSS and to expand research directed at the pathogen and the disease process. In 2001 , large increases in the incidence of PD (35 to $99 \%$ in a single year) were noted in vineyards of the very susceptible variety Red Globe, where the vineyards were within close proximity to citrus (J. Hashim, personal communication).

\section{PD and the Grape Industry in the Southeastern United States}

Impact on production of Vitis vinifera. The situation with PD and the grape industry in Florida is typical for the Gulf Coastal Plain states of South Carolina, Georgia, Alabama, Mississippi, Louisiana, and Texas. Attempts to grow grapes in Florida date from the early Spanish settlement in the sixteenth century (82). The settlers observed the native wild bunch grape, Vitis simpsonii, growing vigorously and reasoned that the European grape, $V$. vinifera, should grow equally well. They introduced varieties of grape from Europe, but these early plantings failed, as have all succeeding efforts to grow varieties of $V$. vinifera in Florida and much of the southeastern United States.

Vectors of $\boldsymbol{X}$. fastidiosa. Several species of leafhoppers have been reported to be important vectors of $X$. fastidiosa in the southeastern United States $(1,3,50)$. These include GWSS (H. coagulata), Oncometopia orbona, O. nigricans, Graphocephala versuta, and Cuerna costalis. These vectors occur commonly throughout the Southeast and can transmit strains of $X$. fastidiosa that cause diseases other than PD (84). In Florida, three of these species of sharpshooter leafhoppers reproduce on grapevines (2). Two of them, GWSS and $O$. nigricans, are large (11 to $13 \mathrm{~mm}$ in length) and are commonly found on the shoots and canes of grapevines. G. versuta, measuring about $5 \mathrm{~mm}$ in length, feeds mainly on leaves. Because of their wide host range on perennial plants and dispersal to grapevines in the spring, the two large species are considered to be most important in the epidemiology of PD in Florida and the Southeast.

$O$. nigricans and $H$. coagulata survive the winter in the adult stage on a number of perennial hosts (1). During the winter, these adults feed, make short flights in warm weather, and often drop to the ground under host plants during cold weather. They are revived by warm temperatures during the day. From early March through April, O. nigricans adults disperse from winter to spring/summer hosts where oviposition and nymphal development take place. Movement of $H$. coagulata to spring hosts for oviposition occurs about a month later than movement of $O$. nigricans.

Alternate hosts of PD strains of $X$. fastidiosa. In the leafhopper ecology study in Florida mentioned above, 13 plants were listed as potential natural hosts of $X$. fastidiosa, because the leafhopper vectors were abundant on these plants (1). Of the 13 plants on the list, four were found to be naturally infected with the PD strain of $X$. fastidiosa and two with non-PD pathotypes of $X$. fastidiosa (38).

PD strains of $X$. fastidiosa are endemic in Florida, and many natural hosts of the bacterium have been reported (38). These hosts include wild grapevines (Vitis spp.), Virginia creeper (Parthenocissus quinquefolia), peppervine (Ampelopsis arborea), American elder (Sambucus canadensis), American beautyberry (Callicarpa americana), blackberry (Rubus sp.), and lupine (Lupinus aridorum). Symptoms were observed in all of these hosts, but their role in the epidemiology of PD in Florida has not been clearly defined. We would expect the symptomatic hosts to represent a larger reservoir of bacteria and be more significant than the symptomless hosts.

Epidemiological characteristics that make PD devastating in the Gulf Coastal Plains states. Contrary to California, where epidemiological studies have been conducted on PD in the Napa Valley
$(57,58)$, epidemiological analyses have not been done on PD in the Gulf Coastal Plains states. It is very difficult to obtain good epidemiological data because of the small vineyard sizes, abundant vector habitats throughout the region, and widespread occurrence of alternate hosts of the PD strain of $X$. fastidiosa in these states. Therefore, much of the information on the development of PD in this area of the United States is based on observations of the relationships between infective vectors, alternate hosts, and PD spread and development.

To understand the epidemiology of PD, it is important to look at movement patterns of the vectors and how these patterns relate to the population sizes and distribution of the PD strain of $X$. fastidiosa in various host plants. In Florida, overwintering populations of leafhoppers were not naturally infective with the PD strain of $X$. fastidiosa on their winter hosts or during dispersal in March to early April from the winter hosts to spring hosts such as grapevine $(1,2)$. There was an extended period of 6 to 10 weeks between first flights of $O$. nigricans to the vineyard and the time that the insects became infective. In these studies, the earliest transmission of PD by naturally infective leafhoppers from cultivated grapevines was late April; earliest transmission by leafhoppers collected from weeds was mid-May; and the earliest transmission by leafhoppers from wild grapevines ( $V$. munsoniana) was late May. These observations correlate very well with how populations of bacteria in stems and petioles of infected grapevines change seasonally (40). Leafhoppers did not become infective on grapevines until bacterial populations in grapevines were high.

By the time the first generation of $O . n i$ gricans or $H$. coagulata dispersed to new hosts in April to May or June, respectively, the PD strain of $X$. fastidiosa was available in a wide variety of plants at transmissible levels $(1,2)$. This dispersal and the secondgeneration dispersal of $O$. nigricans in July and $H$. coagulata in August provide excellent opportunities for leafhoppers to acquire and transmit the PD strain of X. fastidiosa. Natural infectivity of leafhoppers collected from weeds became fairly common in June through the fall.

In Florida, first symptoms of PD in transplanted susceptible grape cultivars were most frequently observed during June through August, probably resulting from April to May leafhopper transmission of the bacterium (33). Susceptible cultivars transplanted in February usually developed symptoms in June or July; whereas those transplanted in early June did not develop symptoms until June of the following year. Either natural field transmission primarily occurred prior to June, or late-season transmissions in the field did not develop symptoms until the following season.

Why does PD prevent the production of $V$ vinifera grapes in the Gulf Coastal 
Plains states and not in other areas where grapes are grown? It apparently is not vector efficiency, since vectors native to California such as the blue-green sharpshooter (Hordnia circellata) are very efficient in transmitting the bacterium to grapevine; whereas $O$. nigricans and $H$. coagulata generally have low transmission rates. It does not appear to be due to the large number of alternate hosts of the bacterium in Florida, because leafhopper vectors from the alternate hosts are not infective in the early spring and do not become infective until bacterial titer is high in grapevine.

One explanation for the severity of PD in the Gulf Coastal Plains states is that it is a "compound interest" disease typical of diseases where vine-to-vine spread is a dominant feature. Spread of PD in Florida was proposed to be primarily from secondary spread (vine-to-vine) within vineyards, especially early in the season when infection is more likely to result in chronic disease (2). Later in the season, exponential spread of PD could involve infective leafhoppers from alternate hosts as well as from infected grapevines. The Florida climate differs dramatically from California in the amount and timing of rainfall, but perhaps more importantly for PD, Florida has warmer nights and a longer growing season. For example, in Florida, where PD is severe and limits bunch grape production, grapevines begin new growth in late February or in March; the largest populations of bacteria in the stems and leaves of the plant occur 4 to 6 weeks before harvest (34), in May, June, and July, which is about 2 months earlier than in California (80). Fruit is harvested in July in Florida, where favorable temperatures for bacterial colonization and systemic spread within the grapevine continue generally into November or December. In contrast, comparable coastal California grape cultivars are harvested from September until November and go dormant in middle to late November. Warm nights in Florida increase the heat units (day-degrees above the growth temperature threshold) per season and support the uninterrupted multiplication of $X$. fastidiosa; whereas cool nights in California below $15^{\circ} \mathrm{C}$ could interrupt bacterial growth daily (16). Perhaps this extended growing season in Florida allows a longer period during which prolonged and more rapid bacterial growth can establish chronic infections in middle or even late summer. In contrast, areas with cooler winter climates, such as California, usually have a much shorter growing season, and cold weather, unfavorable for bacterial colonization, triggers dormancy in the grapevines at the time of fruit maturation. In this case, the bacteria may be limited to smaller branches, which may be removed by winter pruning or in which the bacteria are more vulnerable to cold winter temperatures. We suggest it is the combination of the "compound interest" type spread and the longer growing season for chronic infection to occur that make PD such a devastating disease in the Gulf Coastal Plains states.

\section{Current Control Strategies}

Host resistance. The only feasible control for PD in the southeastern United States and parts of California is genetically controlled plant resistance to $X$. fastidiosa. Maintenance of a productive lifespan of grapes in the Gulf Coastal Plains states of the United States requires the use of resistant varieties. Nearly all popular grape cultivars of European-type ( $V$. vinifera), American-type ( . labrusca), and FrenchAmerican hybrid grapes are killed by PD. Resistance to PD was found in Vitis species native to the southeastern United States $(25,53)$. The grape industry in this area of the country is based on these resistant Vitis species.

A major factor in the popularity of muscadine grapes (V. rotundifolia) in the southeastern United States is their high resistance, or tolerance, to PD, as expressed by their vigor and longevity (47). Muscadine cultivars are not immune to PD, and some of them do not have enough tolerance to perform acceptably in Florida (39).

Among grape species and cultivars, there appears to be a complete spectrum of tolerance to $\mathrm{PD}$, ranging from the most resistant muscadine and Florida hybrid cultivars to the most susceptible $V$. vinifera cultivar. However, in California, differences in tolerances have been reported among $V$. vinifera cultivars $(57,71)$. Mapping indicated that there were significant varietal differences in susceptibility to PD in the Napa Valley, with 'Pinot noir' and 'Flora' having higher incidences of PD than 'Petit Sirah', 'Chenin blanc', and 'Sylvaner'. X. fastidiosa populations in inoculated cuttings of these cultivars appeared to relate to the intensity of disease development in the Napa Valley vineyards (71).

Vector control. Vector control efforts have not succeeded in halting PD in California or in Florida $(24,51)$. In Napa Valley, CA, early spring insecticide treatments of natural vegetation and grapevines along vineyard borders reduced the number of PD vectors entering vineyards for 2 months (60). Reduced rates of spread of PD were apparent 1 year later in moderately susceptible grape varieties, but not in the very susceptible varieties 'Pinot Noir' and 'Pinot Chardonnay'. This ineffectiveness of insecticides on more susceptible cultivars may be due to the longer time period during which chronic infections can be established (62). The speed of movement of PD symptoms, and presumably of $X$. fastidiosa, from a single point of infection seemed to be related to the degree of susceptibility.

In Florida, the failure of insecticidal control of vectors to reduce PD may have been due to the small plot sizes (51) or longer period that vines must be protected from chronic infection. In large plots or vineyards in Florida, insecticide sprays may provide some control, since secondary spread within the vineyard appears to be most significant (2). Because PD spread is primarily within the vineyard and there is an extended period ( 6 to 10 weeks) between the first flights of $O$. nigricans to the vineyard and first transmission, an insecticide spray program could be initiated after the arrival of $O$. nigricans in the vineyard in the spring. Emphasis should be on preventing the early (spring) arrival of sharpshooter vectors on the vines.

Cultural practices. In many hosts, symptoms caused by $X$. fastidiosa first develop only after the host plant is weakened by some other factor. PD symptoms often become severe only after some other stress is placed on the vine. Stress factors observed to favor PD development include drought, root pruning with cultivation equipment, other diseases, overproduction of fruit, and normal plant senescence $(35,40)$. The PD bacterium accumulates in the older, more mature tissue and is not found in young, juvenile tissue (40). The plant stress factors that favor the development of PD symptoms all promote plant senescence, and the PD symptoms in grapevine-chlorosis, abscission of leaves, and acropetal development of symptomsare also characteristic of senescence. Thus, cultural practices that maintain the grapevine in a healthy, actively growing condition can reduce the severity of PD symptoms in some situations, especially in grape cultivars that have some genetic tolerance to PD.

\section{Future Outlook for Disease Management}

Complete genome sequence for $X$. fastidiosa. The recently completed sequencing and annotation of the complete genome of the CVC strain of $X$. fastidiosa (79) provided a new focus of using genomic information from the pathogen to speed the search for a solution. The sequencing of the complete genomes of four strains of $X$. fastidiosa has revealed gene homologies that permit estimating the function of almost half of its genes (open reading frames, sequences that imply function as a gene). These include a number of potential pathogenicity mechanisms for this bacterium such as toxins, antibiotics, and iron sequestration systems. Other genes possibly involved in pathogenicity or host specificity include those for the production of extracellular polysaccharides, or EPS $(11,79)$, that might be involved in blocking water transport. $X$. fastidiosa has sequences homologous with the gum operon of the bacterium Xanthomonas campestris, but lacks three of the genes needed for the synthesis of xanthan gum, the EPS produced by $X$. campestris. This suggests that 
$X$. fastidiosa synthesizes a different EPS than xanthan gum (11). Notably, X. fastidiosa lacks avr genes or genes involved in Type III secretion systems (79).

Cross-protection with avirulent, or weakly virulent, strains of $X$. fastidiosa. Virulence to grape of $X$. fastidiosa strains originally obtained from grapevines with PD varies from avirulent to highly virulent. Weakly virulent strains multiply and move systemically, but more slowly in the plant, producing only minor symptoms in the host. In greenhouse tests, weakly virulent strains of $X$. fastidiosa were used to inoculate lower internodes of $V$. vinifera 'Carignane'. Inoculation of these plants 2 weeks later with a highly pathogenic strain of the bacterium resulted in a lower incidence and severity rating for PD than for the plants that had not been protected with weakly virulent strains (37). The effective strains included strains from PD of grapevine that had lost their virulence to grape in serial transfer and a strain originally from sycamore.

In the early spring of 1997 , a planting of 'Cabernet Sauvignon' on 'Freedom' rootstock was established in the University of Florida vineyard at the research center in Leesburg. These plants were inoculated with strains of $X$. fastidiosa that were avirulent, or weakly virulent, to grapevine as soon as new shoot growth was 18 to 30 inches long, and received no additional injections with the protectant strains, that were originally obtained from grapevine, elderberry, or sycamore. PD is endemic and severe in this vineyard, and plants are infected within months of planting. The plants were rated for PD symptoms through March 2001. After 48 months, all of the untreated vines were dead. In grapevines injected with one strain of $X$. fastidiosa, originally isolated from elderberry, there was no loss for 36 months, and only one vine had died after 48 months.

Possibly, one of these naturally occurring weakly virulent strains of $X$. fastidiosa could be used to develop a biological control system for PD. Alternatively, specific genes that are involved in the pathogenicity of $X$. fastidiosa to grapevine could be identified and disrupted using molecular methods. These strains that are avirulent because of very site-specific mutations might be useful for cross protection against PD.

Genetic engineering for resistance in grapevine. Conventional plant breeding has utilized grape species native to the southeastern United States as sources of resistance to PD strains of $X$. fastidiosa. Highly resistant bunch grape and muscadine cultivars have been developed. While these cultivars have excellent resistance to $\mathrm{PD}$, most of them lack the fruit quality to compete with $V$. vinifera wine and table grapes. For wine grapes, traditional cultivars are essential for marketing the crop. This requirement makes genetic engineer- ing a promising approach for incorporating resistance genes into popular varietal wine cultivars without affecting other characteristics of the grape.

Genes for several lytic peptides that have antibacterial activity have been cloned from arthropods and mammals. Somatic embryos of grapes have been transformed with some of these lytic peptide genes. Protein product from at least one of these genes has been detected in xylem sap with enzyme-linked immunosorbent assay (ELISA). The effectiveness of these lytic peptide genes for resistance to PD has not yet been established. Alternatively, resistance genes could be identified in resistant grapevines native to the southeastern United States and incorporated into susceptible $V$. vinifera grapes. This approach might have the advantage of a wider public acceptance of grapevines genetically engineered with other grape genes than of grapevines engineered with genes from more diverse sources. This approach will be difficult because inheritance of resistance to PD in Vitis appears to be multigenic (52). These genetic engineering approaches are not short-term solutions. Because grape is a perennial crop in which specific cultivars are required for the production of varietal wine, genetically engineered grapevines would require years of testing to demonstrate resistance and the presence of identical varietal traits with the original cultivar.

Future for other diseases caused by $X$. fastidiosa? Given the startling increase in problems caused by $X$. fastidiosa over the past 10 years, we can confidently predict that we have not seen the last of "new" plant diseases that this bacterium provokes. In many cases, these "new" diseases will be long-established disorders that have been attributed to other causes. A recent example is "pecan fungal leaf scorch", which was proven to be caused by X. fastidiosa (74) in the southeastern United States. In other cases, we can expect to see diseases result from new pathogen (strain)host plant combinations that result from the introduction of exotic strains.

The various leaf scorch diseases of native forest trees in the southeastern United States probably cause more environmental damage to forests and economic damage to timber and pulp production than to crops. A major challenge will be to prevent the introduction or spread of exotic strains of $X$. fastidiosa. The western United States apparently lacks strains such as oak, sycamore, or elm that cause leaf scorch diseases. The CVC strain of $X$. fastidiosa has the potential to threaten orange production in Central and North America. Moreover, CVC and coffee strains can cause disease in grape under greenhouse conditions (J. Hartung, personal communication). If these strains became widespread in citrus in California, not only would citrus be drastically affected, but the percentages of
GWSS carrying grape-pathogenic $X$. fastidiosa and entering vineyards from nearby citrus groves would greatly increase, as citrus does not seem to be a major source of inoculum for PD strains of X. fastidiosa in California to date (R. Almeida and W. Feil, personal communications). X. fastidiosa could become serious, even croplimiting, problems in grape, orange, and other crops in subtropical or tropical Australia, Europe, Asia, and Africa. Perhaps a key ingredient that has been missing in these regions so far free of $X$. fastidiosa is a suitable vector. The California experience with GWSS has demonstrated the critical role of such a vector. This newly introduced vector now threatens the economic survival of grape and almond crops in areas of the state that previously had no PD or ALS problems.

\section{Literature Cited}

1. Adlerz, W. C. 1980. Ecological observations on two leafhoppers that transmit the Pierce's disease bacterium. Proc. Fla. State Hortic. Soc. 93:115-120.

2. Adlerz, W. C., and Hopkins, D. L. 1979. Natural infectivity of two sharpshooter vectors of Pierce's disease of grape in Florida. J. Econ. Entomol. 72:916-919.

3. Ball, J. C. 1979. Seasonal patterns of activity of adult leafhopper vectors of phony peach disease in Florida. Environ. Entomol. 8:686688.

4. Berisha, B., Chen, Y. D., Zhang, G. Y., Xu, B. Y., and Chen, T. A. 1998. Isolation of Pierce's disease bacteria from grapevines in Europe. Eur. J. Plant Pathol. 104(5):427-433.

5. Blua, M. J., Phillips, P. A., and Redak, R. A. 1999. A new sharpshooter threatens both crops and ornamentals. Calif. Agric. 53(2):2225.

6. Chang, C. J., Garnier, M., Zreik, L., Rossetti, V., and Bove, J. M. 1993. Culture and serological detection of the xylem-limited bacterium causing citrus variegated chlorosis and its identification as a strain of Xylella fastidiosa. Curr. Microbiol. 27:137-142.

7. Chang, C. J., and Walker, J. T. 1988. Bacterial leaf scorch of northern red oak: Isolation, cultivation, and pathogenicity of a xylem-limited bacterium. Plant Dis. 72:730-733.

8. Cochran, L. C., Weinberger, J. H., and Turner, W. F. 1951. Natural occurrence of the phony peach virus in wild chicksaw plums near peach orchards in Georgia. Plant Dis. Rep. 35:181-182.

9. Contreras, J. del V. 1992. Pecosita ou falsa mancha grasienta na Argentina. Laranja Cia 31(6):4.

10. Costa, P. I., Franco, C. F., Miranda, V. S., Teixeira, D. C., and Hartung, J. S. 1999 Strains of Xylella fastidiosa rapidly distinguished by arbitrarily primed-PCR. Curr. Microbiol. 40:279-282.

11. Da Silva, F. R., Vettore, A. L., Kemper, E. L., Leite, A., and Arruda, P. 2001. Fastidian gum: The Xylella fastidiosa exopolysaccharide possibly involved in bacterial pathogenicity. FEMS Microbiol. Lett. 203(2):165-171.

12. Davis, M. J., Purcell, A. H., and Thomson, S. V. 1978. Pierce's disease of grapevines: Isolation of the causal bacterium. Science 199:7577.

13. Davis, M. J., Raju, B. C., Brlansky, R. H. Lee, R. F., Timmer, L. W., Norris, R. C., and McCoy, R. E. 1983. Periwinkle wilt bacterium: Axenic culture, pathogenicity, and relationships to other gram-negative, xylem- 
inhabiting bacteria. Phytopathology 73:15101515.

14. Davis, M. J., Thomson, S. V., and Purcell, A. H. 1980. Etiological role of a xylem-limited bacterium causing Pierce's disease in almond leaf scorch. Phytopathology 70:472-475.

15. de Lima, J. E. O., Miranda, V. S., Hartung, J. S., Brlansky, R. H., Coutinho, A., Roberto, S. R., and Carlos, E. F. 1998. Coffee leaf scorch bacterium: Axenic culture, pathogenicity, and comparison with Xylella fastidiosa of citrus. Plant Dis. 82:94-97.

16. Feil, H., and Purcell, A. H. 2001. Temperature-dependent growth and survival of Xylella fastidiosa in vitro and in potted grapevines. Plant Dis. 85:1230-1234.

17. Frazier, N. W., and Freitag, J. H. 1946. Ten additional leafhopper vectors of the virus causing Pierce's disease of grapes. Phytopathology 36:634-637.

18. Freitag, J. H. 1951. Host range of Pierce's disease virus of grapes as determined by insect transmission. Phytopathology 41:920934.

19. French, W. J., and Kitajima, E. W. 1978. Occurrence of plum leaf scald in Brazil and Paraguay. Plant Dis. Rep. 62:1035-1038.

20. Goodwin, P. H., and Zhang, S. 1997. Distribution of Xylella fastidiosa in southern Ontario as determined by the polymerase chain reaction. Can. J. Plant Pathol. 19:13-18.

21. Hartman, J. R., Kaiser, C. A., Jarlfors, U. E., Eshenaur, B. C., Bachi, P. A., and Dunwell, W. C. 1991. Occurrence of oak bacterial leaf scorch caused by Xylella fastidiosa in Kentucky. Plant Dis. 75:862.

22. Hartung, J. S., Beretta, J., Brlansky, R. H., Spisso, J., and Lee, R. F. 1994. Citrus variegated chlorosis bacterium: Axenic culture, pathogenicity, and serological relationships with other strains of Xylella fastidiosa. Phytopathology 84:591-597.

23. Hearon, S. S., Sherald, J. L., and Kostka, S. J. 1980. Association of xylem-limited bacteria with elm, sycamore, and oak leaf scorch. Can. J. Bot. 58:1986-1993.

24. Hewitt, W. B. 1970. Pierce's disease of Vitis species. Pages 196-200 in: Virus Disease of Small Fruits and Grapevines. N. W. Frazier, ed. University of California Press, Berkeley.

25. Hewitt, W. B. 1958. The probable home of Pierce's disease virus. Plant Dis. Rep. 42:211215 .

26. Hewitt, W. B., Frazier, N. W., and Freitag, J. H. 1949. Pierce's disease investigations. Hilgardia 19:207-264.

27. Hewitt, W. B., Frazier, N. W., Jacob, H. E., and Freitag, J. H. 1942. Pierce's disease of grapevines. Calif. Agric. Exp. Stn. Circ. 353:1-32.

28. Hewitt, W. B., and Houston, B. R. 1941. Association of Pierce's disease and alfalfa dwarf in California. Plant Dis. Rep. 25:475476.

29. Hewitt, W. B., Houston, B. R., Frazier, N. W., and Freitag, J. H. 1946. Leafhopper transmission of the virus causing Pierce's disease of grape and dwarf of alfalfa. Phytopathology 36:117-128.

30. Hill, B. L., and Purcell, A. H. 1995. Multiplication and movement of Xylella fastidiosa within grape and four other plants. Phytopathology 85:1368-1372.

31. Hill, B. L., and Purcell, A. H. 1997. Populations of Xylella fastidiosa in plants required for transmission by an efficient vector. Phytopathology 87:1197-1201.

32. Hopkins, D. L. 1976. Pierce's disease of grapevines. Am. Wine Soc. J. 8:26-27.

33. Hopkins, D. L. 1977. Diseases caused by leafhopper-borne rickettsia-like bacteria. Annu. Rev. Phytopathol. 17:277-294.

34. Hopkins, D. L. 1981. Seasonal concentration of the Pierce's disease bacterium in grapevine stems, petioles, and leaf veins. Phytopathology 71:415-418.

35. Hopkins, D. L. 1985. Effects of plant growth regulators on development of Pierce's disease symptoms in grapevine. Plant Dis. 69:944946.

36. Hopkins, D. L. 1988. Xylella fastidiosa: Xylem-limited bacterial pathogen of plants. Annu. Rev. Phytopathol. 27:271-290.

37. Hopkins, D. L. 1992. Induced resistance to Pierce's disease of grapevine by weakly virulent strains of Xylella fastidiosa. Proc. Int. Conf. Plant Pathol. Bacteria, 8th. pp. 951-956.

38. Hopkins, D. L., and Adlerz, W. C. 1988. Natural hosts of Xylella fastidiosa in Florida. Plant Dis. 72:429-431.

39. Hopkins, D. L., Mollenhauer, H. H., and Mortensen, J. A. 1974. Tolerance to Pierce's disease and the associated rickettsia-like bacterium in muscadine grape. J. Am. Soc. Hortic. Sci. 99:436-439.

40. Hopkins, D. L., and Thompson, C. M. 1984. Seasonal concentration of the Pierce's disease bacterium in 'Carlos' and 'Welder' muscadine grapes compared with 'Schuyler' bunch grape. HortScience 19:419-420.

41. Houston, B. R., Esau, K., and Hewitt, W. B. 1947. The mode of vector feeding and the tissues involved in the transmission of Pierce's disease virus in grape and alfalfa. Phytopathology 37:247-253.

42. Kitajima, E. W., Bakarcic, M., and FernandezValiela, M. V. 1975. Association of rickettsialike bacteria with plum leaf scald disease. Phytopathology 65:476-478.

43. Kostka, S. J., Tattar, T. A., Sherald, J. L., and Hurtt, S. S. 1986. Mulberry leaf scorch, new disease caused by a fastidious, xylem-inhabiting bacterium. Plant Dis. 70:690-693.

44. Laranjeira, F. F. 1997. Ten years of citrus variegated chlorosis: What do we know? Laranja (Cordeopolis, Brazil) 18:123-141.

45. Leu, L. S., and Su, C. C. 1993. Isolation, cultivation, and pathogenicity of Xylella fastidiosa, the causal bacterium of pear leaf scorch disease in Taiwan. Plant Dis. 77:642646.

46. Li, W.-B., Pria, W. D., Jr., Teixeira, D. C., Miranda, V. S., Ayres, A. J., Franco, C. F., Costa, M. G., He, C.-X., Costa, P. I., and Hartung, J. S. 2001. Coffee leaf scorch caused by a strain of Xylella fastidiosa from citrus. Plant Dis. 85:501-505.

47. Loomis, N. H. 1958. Performance of Vitis species in the south as an indication of their relative resistance to Pierce's disease. Plant Dis. Rep. 42:833-836.

48. McCoy, R. E., Thomas, D. L., Tsai, J. H., and French, W. J. 1978. Periwinkle wilt, a new disease associated with xylem delimited rickettsia-like bacteria transmitted by a sharpshooter. Plant Dis. Rep. 62:1022-1026.

49. Mircetich, S. M., Lowe, S. K., Moller, W. J., and Nyland, G. 1976. Etiology of almond leaf scorch disease and transmission of the causal agent. Phytopathology 66:17-24.

50. Mizell, R. F., and French, W. J. 1987. Leafhopper vectors of phony peach disease: Feeding site preference and survival on infected and uninfected peach, and seasonal response to selected host plants. J. Entomol. Sci. 22:11-22.

51. Mortensen, J. A. 1966. Comparative growth and yield of ten grape varieties sprayed intensively for insect and disease control. Proc. Fla. State Hortic. Soc. 79:390-395.

52. Mortensen, J. A. 1968. The inheritance of resistance to Pierce's disease in Vitis. Proc. Am. Soc. Hortic. Sci. 92:331-337.

53. Mortensen, J. A., Stover, L. H., and Balerdi, C. F. 1977. Sources of resistance to Pierce's disease in Vitis. J. Am. Soc. Hortic. Sci.
102:695-697.

54. Nome, S. F., Haelterman, R. M., and Docampo, D. M. 1992. Escaldadura de las hojas del almendro in Argentina. Fitopatol. Bras. 17:57-60.

55. Perring, T. M., Farrar, C. A., and Blua, M. J. 2001. Proximity to citrus influences Pierce's disease in Temecula Valley vineyards. Calif. Agric. 55:13-18.

56. Pierce, N. B. 1882 . The California vine disease. U.S. Dep. Agric., Div. Veg. Pathol. Bull No. 2.

57. Purcell, A. H. 1974. Spatial patterns of Pierce's disease in the Napa Valley. Am. J. Enol. Vitic. 25:162-167.

58. Purcell, A. H. 1975. Role of the blue-green sharpshooter, Hordnia circellata, in the epidemiology of Pierce's disease of grapevines. Environ. Entomol. 4:745-752.

59. Purcell, A. H. 1979. Leafhopper vectors of xylem-borne plant pathogens. Pages 603-625 in: Leafhopper Vectors and Plant Disease Agents. K. Maramorosch and K. F. Harris, eds. Academic Press, New York.

60. Purcell, A. H. 1979. Control of the blue-green sharpshooter and effects on the spread of Pierce's disease of grapevines. J. Econ. Entomol. 72:887-892.

61. Purcell, A. H. 1980. Environmental therapy for Pierce's disease of grapevines. Plant Dis. 64:388-390.

62. Purcell, A. H. 1981. Vector preference and inoculation efficiency as components of resistance to Pierce's disease in European grape cultivars. Phytopathology 71:429-435.

63. Purcell, A. H. 1997. Xylella fastidiosa, a regional problem or global threat? J. Plant Pathol. 79(2):99-105.

64. Purcell, A. H., and Feil, H. 2001. Glassywinged sharpshooter. Pestic. Outlook 11:199 203.

65. Purcell, A. H., and Finlay, A. H. 1979. Evidence for noncirculative transmission of Pierce's disease bacterium by sharpshooter leafhoppers. Phytopathology 69:393-395.

66. Purcell, A. H., and Frazier, N. W. 1985. Habitats and dispersal of the leafhopper vectors of Pierce's disease in the San Joaquin Valley. Hilgardia 53(4):1-32.

67. Purcell, A. H., and Hopkins, D. L. 1996 Fastidious xylem-limited bacterial plant pathogens. Annu. Rev. Phytopathol. 34:131151.

68. Purcell, A. H., and Saunders, S. R. 1999. Fate of Pierce's disease strains of Xylella fastidiosa in common riparian plants in California. Plant Dis. 83:825-830.

69. Purcell, A. H., and Saunders, S. R. 1999. Glassy-winged sharpshooters expected to increase plant disease. Calif. Agric. 53(2):26-27.

70. Purcell, A. H., Saunders, S. R., Hendson, M. E., Grebus, M. E., and Henry, M. J. 1999. Causal role of Xylella fastidiosa in oleander leaf scorch disease. Phytopathology 89:53-58.

71. Raju, B. C., and Goheen, A. C. 1981. Relative sensitivity of selected grapevine cultivars to Pierce's disease bacterial inoculations. Am. J. Enol. Vitic. 32:155-158

72. Roberto, S. R., Dalla Pria, W., Jr., Yamamoto, P. T., Fellipe, M. R., and de Freitas, E. P 2000. Espécies e flutuação populacional de cigarrinhas em viveiro de citros, em gavião Peixoto (SP), Laranja (Cordeopolis, Brazil) 21(1):65-80.

73. Rossetti, V., Garnier, M., Bove, J. M., Beretta, M. J. g., Teixeira, A. R. R., Quaggio, J. A. and Negri, J. D. D. 1990. Occurrence of xylem-restricted bacteria in sweet orange trees affected by chlorotic variegation, a new citrus disease in Brazil. Comptes Rendus de l'Academie des Sciences Serie III Sciences de la Vie. 310(8):345-350.

74. Sanderlin, R. S., and Heyderich-Alger, K. I. 
2000. Evidence that Xylella fastidiosa can cause leaf scorch disease of pecan. Plant Dis. 84:1282-1286.

75. Severin, H. H. P. 1949. Transmission of the virus of Pierce's disease by leafhoppers. Hilgardia 19:190-202.

76. Sherald, J. L. 1993. Pathogenicity of Xylella fastidiosa in American elm and failure of reciprocal transmission between strains from elm and sycamore. Plant Dis. 77:190-193.

77. Sherald, J. L., Hearon, S. S., Kostka, S. J., and Morgan, D. L. 1983. Sycamore leaf scorch: Culture and pathogenicity of fastidious xylem-limited bacteria from scorch-affected trees. Plant Dis. 67:849-852.

78. Sherald, J. L., Wells, J. M., Hurtt, S. S., and Kostka, S. J. 1987. Association of fastidious, xylem-inhabiting bacteria with leaf scorch in red maple. Plant Dis. 71:930-933

79. Simpson, A. J. G., Reinach, F. C., Arruda, P., Abreu, F. A., Acencio, M., Alvarenga, R., Alves, L. M. C., Araya, J. E., Baia, G. S., Baptista, C. S., et al. 2000. The genome sequence of the plant pathogen Xylella fastidiosa. Nature (London) 406(6792):151-157.

80. Smart, C. D., Hendson, M., Guilhabert, M. R., Saunders, S., Friebertshauser, G., Purcell, A. H., and Kirkpatrick, B. C. 1998. Seasonal detection of Xylella fastidiosa in grapevines with culture, ELISA and PCR. Phytopathology 88:S83.

81. Sorensen, J. T., and Gill, R. J. 1996. A range extension of Homalodisca coagulata (Say) (Hemiptera: Clypeorrhyncha: Cicadellidae) to southern California. Pan-Pacific Entomol. 72(3):160-161.

82. Stoner, W. N. 1953. Leafhopper transmission of a degeneration of grape in Florida and its relation to Pierce's disease. Phytopathology 43:611-615

83. Thomson, S. V., Davis, M. J., Kloepper, J. W., and Purcell, A. H. 1978. Alfalfa dwarf: Relationship to the bacterium causing Pierce's disease of grapevines. (Abstr.) Proc. Intl. Congr. Plant Pathol., 3rd. 3:65.

84. Turner, W. F., and Pollard, H. N. 1959. Life histories and behavior of five insect vectors of phony peach disease. U.S. Dep. Agric. Tech. Bull. No. 1188 .

85. Turner, W. F., and Pollard, H. N. 1959. Insect transmission of phony peach disease. U.S. Dep. Agric. Tech. Bull. 1193.

86. Van der Plank, J. E. 1963. Plant Diseases: Epidemics and Control. Academic Press, New York.

87. Weimer, J. L. 1931. Alfalfa dwarf, a hitherto unreported disease. Phytopathology 21:71-75.

88. Weimer, J. L. 1937. Effect of the dwarf disease on the alfalfa plant. J. Agric. Res. 55:87104.

89. Wells, J. M., Raju, B. C., Hung, H. Y., Weisburg, W. G., Mandelco-Paul, L., and Brenner, D. J. 1987. Xylella fastidiosa gen. nov. sp. Nov.: Gram-negative, xylem-limited fastidious plant bacteria related to Xanthomonas spp. Int. J. Syst. Bacteriol. 37:136-143.

90. Wells, J. M., Raju, B. C., and Nyland, G. 1983. Isolation, culture and pathogenicity of the bacterium causing phony disease of peach. Phytopathology 73:859-862.

91. Wells, J. M., Raju, B. C., Thomson, J. M., and
Lowe, S. K. 1981. Evidence of the common etiology of phony peach and plum leaf scald diseases. Phytopathology 71:1156-1161.

92. Wester, H. V., and Jylkka, E. W. 1959. Elm leaf scorch, graft transmissible virus of American elm. Plant Dis. Rep. 43:519.

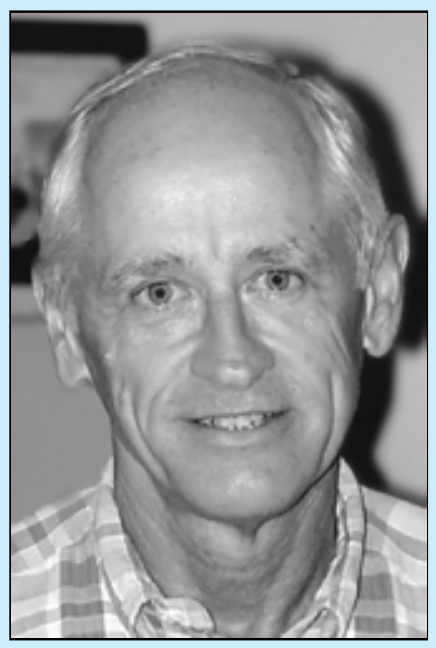

Donald L. Hopkins

Dr. Hopkins is a professor of plant pathology at the University of Florida Mid-Florida Research and Education Center in Apopka. He received his B.S. degree in agriculture and chemistry from Western Kentucky University in 1965 and his Ph.D. in plant pathology from the University of Kentucky in 1968. He completed a 15-month postdoctorate at the University of Wisconsin in 1969 and joined the University of Florida. He immediately began research on Pierce's disease of grapevine and has 30 years of experience working with Pierce's disease of grapevine in Florida, where the disease limits the grape industry. His research is on the epidemiology and control of diseases caused by Xylella fastidiosa and bacterial fruit blotch of cucurbits. His current research with $X$. fastidiosa focuses on molecular methods for distinguishing pathotypes and on the control of Pierce's disease by cross protection with weakly virulent strains of $X$. fastidiosa.

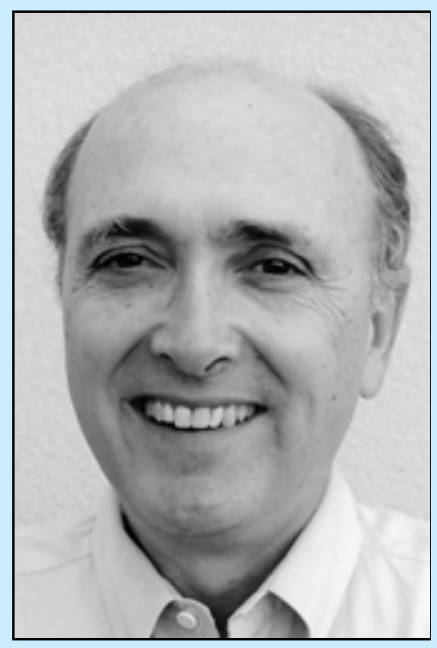

Alexander H. (Sandy) Purcell

Dr. Purcell is a professor of entomology in the Division of Insect Biology at the University of California, Berkeley. He graduated from the U.S. Air Force Academy in 1964 and was a pilot for 6 years before entering Louisiana State University for a year to learn some biology. He received a Ph.D. in entomology from the University of California, Davis, and joined the faculty at Berkeley in 1974. His studies on Pierce's disease began with his graduate research in 1972 His research is on the bacterial ecology of sap-feeding insects, including Xylella fastidiosa, phytoplasmas, and transovarially transmitted bacterial symbiotes of leafhoppers and aphids. He maintains a website at the College of Natural Resources, University of California, Berkeley, that provides links to information on the major diseases caused by Xylella and its vectors. 